\title{
IMPLEMENTATION OF TROPHIC STATUS INDEX IN BRACKISH WATER QUALITY ASSESSMENT OF BALTIC COASTAL WATERS
}

\author{
Elmīra Boikova, Uldis Botva, and Vita Līcìte
}

Institute of Biology, University of Latvia, Miera ielā 3, Salaspils, LV-2169, LATVIA

elmira@ hydro.edu.Iv

Communicated by Jānis Vīksne

\begin{abstract}
The assessment of the trophic state of marine coastal waters is one of the leading initiatives declared in the European Water Framework Directive (WFD). The Baltic Sea is a semi-enclosed ecosystem which consists of subregions with wide salinity and seasonality gradients. Anthropogenic impact results in eutrophication processes on different scales. Efficient eutrophication control and environmental management in the Baltic Sea, according to WFD, requires a prerequisite of common and sensitive indicators for the European coastal waters including the Baltic Sea. In this article the Trophic Status Index TRIX, recently succcesfully implemented in Mediterranean and Northern European sea coastal waters as a holistic approach indicator, was implemented for the Gulf of Riga and Latvian Baltic Sea coastal water quality assessment between 1999 and 2005.
\end{abstract}

Key words: water quality, trophic status index, indicators, Baltic coastal waters.

\section{INTRODUCTION}

Indicators give a partial view of reality, but at the same time they are an important element in the strategy of the environment sustainable development. They serve as tools for making international comparisons, which is one of the basic aims of implementation of the Water Framework Directive in Europe. Indicators are raising public awareness about the environment and informing decision makers. According to UNESCO manuals (Anonymous, 2003), the following traits are characteristics of environmental indicators: a) an agreed, scientifically based meaning, b) representative of an important environmental aspect for the society, c) provide valuable information with a readily understandable meaning, and d) assist decision-making by being efficient and costeffective to use.

In general, ecological indicators are commonly used to assess the state of ecosystems and mainly refer to ecosystem structure and/or functioning, for example, nutrient concentrations, organisms and plant diversity, productivity, etc. From a holistic point of view, only recently scientists have proposed indices able to integrate environmental information. Vollenweider et al. (1998) developed a Trophic Index (TRIX) by integrating four basic ecosystem parameters like chlorophyll $a$, a level of saturation by dissolved oxygen, inorganic nitrogen (the sum of $\mathrm{N}-\mathrm{NH}_{4}, \mathrm{~N}-\mathrm{NO}_{3}, \mathrm{~N}-\mathrm{NO}_{2} \mu \mathrm{M}$ ), and total phosphorus concentrations, to characterise the trophic state of marine coastal waters. The integrative algoritm of TRIX and values of typology were first described using long-term monitoring data sets for Adriatic coastal waters.
The list of Nordic Indicators (2006), which covers also the Baltic Sea, includes several indicators illustrating the trends of environment state-toxins in cod, discharges of heavy metals, discharge of nutrients to the Baltic Sea, but indices based on the holistic approach are still missing.

The Latvian coastline of the Baltic Sea is about $500 \mathrm{~km}$ long, of which $250 \mathrm{~km}(50 \%)$ is along the Gulf of Riga. The gulf is located in the southeastern part of the Baltic Sea and connected with the open sea by two straits (Irbe Strait and Muhu Strait). Thus, water quality can be assessed by the the Trophic Status Index in two different subsystems-the gulf and the sea open coast shallow areas, where the stress from the land is the most pronounced.

The aim of this study was to characterise the water quality of littoral and sublittoral zones in coastal waters of the Southeastern Baltic Sea using TRIX, which combines basic ecosystem parameters.

\section{MATERIALS AND METHODS}

Study area. Figure $1(\mathrm{a}, \mathrm{b})$ and Figure 2 show the southeastern part of the Baltic Sea where littoral and sublittoral stations were located. The sampling depth of all 25 littoral stations was $1 \mathrm{~m}$, and for 10 sublittoral stations (sampling 2001) - 10 m depth and about one nautical mile from the coast (Fig. 2).

Sampling and analyses. In the Gulf of Riga the sampling was carried out from 1999 to 2005 every second year in 


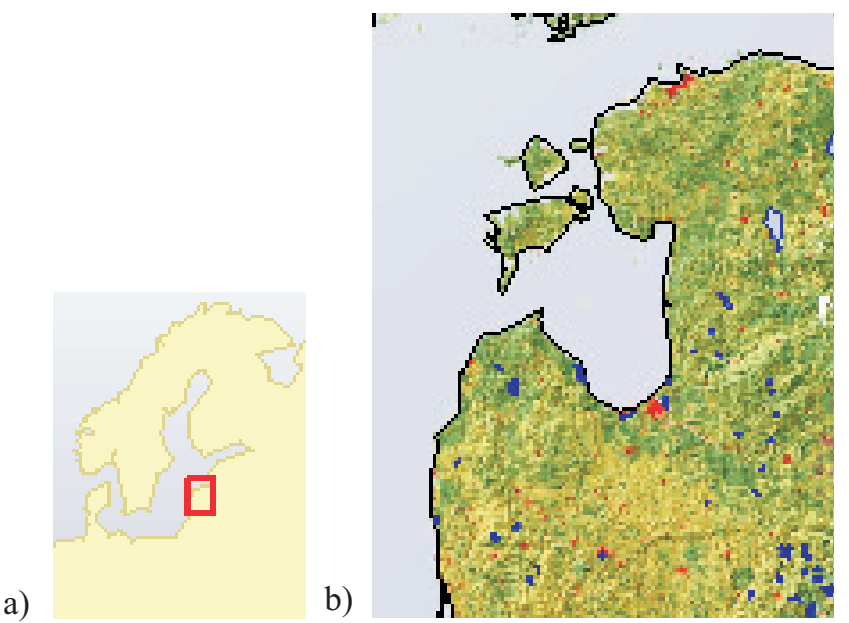

Fig. 1. Maps of the investigation area in the Baltic Sea (a) and the Gulf of Rīga (b).

summer (last week of July/first week of August) and in 2005 also in December. At the Baltic Sea open coast the first survey was performed in July 2005 and during 2006 in late spring (June), summer (July/August), and fall (September).

Surface water was collected and preserved in cold, dark conditions for laboratory analyses. Water samples for chlorophyll $a$ determination were filtered through Whatman $\mathrm{GF} / \mathrm{F}$ filters and frozen until measurement of pigment concentrations. Pigment was extracted with $90 \%$ acetone and determined by spectrophotometry (Parson et al., 1984). Cal- culations were made according to Strickland and Parsons (1972). Nutrient samples were analysed by standard colorimetric techniques (Grasshoff et al., 1983) Dissolved oxygen was measured by a standard Winkler titration (Strickland and Parsons, 1972).

The Trophic State Index (TRIX) (Vollenweider et al., 1998) was calculated as follows:

TRIX $=[\log (\mathrm{Chl} a \times \mathrm{aD} \% \mathrm{O} \times \mathrm{N} \times \mathrm{P})+1,5] / 1,2$,

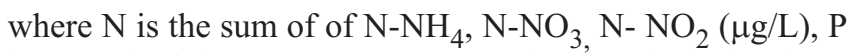
is P-tot $(\mu \mathrm{g} / \mathrm{L}), \mathrm{aD} \% \mathrm{O}$ - oxygen as absolute deviation from saturation (\%) and productivity as chlorophyll $a\left(\mathrm{mg} / \mathrm{m}^{3}\right)$.

Numerically the Index is scaled from 0 to 10 and covers a wide range of trophic conditions. The SURFER 8 programme was used for the plotting of TRIX values in littoral/sublittoral zone.

\section{RESULTS}

Physical, chemical parameters and TRIX in the Gulf of Rīga. The mean water temperature during investigated periods oscillated between $12.0{ }^{\circ} \mathrm{C}$ and $23.5{ }^{\circ} \mathrm{C}$. The low minimum temperature in summer was caused by coastal upwelling. The salinity ranged from $3.77 \mathrm{psu}$ to $5.61 \mathrm{psu}$ and dissolved oxygen from 6.04 to $7.41 \mathrm{ml} / 1$ (Table 1). Chlorophyll $a$ values in the Gulf of Riga littoral stations were highly variable. For example, in 1999 the minimum value of $3.3 \mathrm{mg} / \mathrm{m}^{3}$ was recorded, and the maximum-22.6 $\mathrm{mg} / \mathrm{m}^{3}$ in 2005 . Dissolved inorganic nitrogen $(\mu \mathrm{M})$ the sum of $\mathrm{N}-\mathrm{NH}_{4}, \mathrm{~N}-\mathrm{NO}_{3}, \mathrm{~N}-\mathrm{NO}_{2}$, tended to decrease from year to

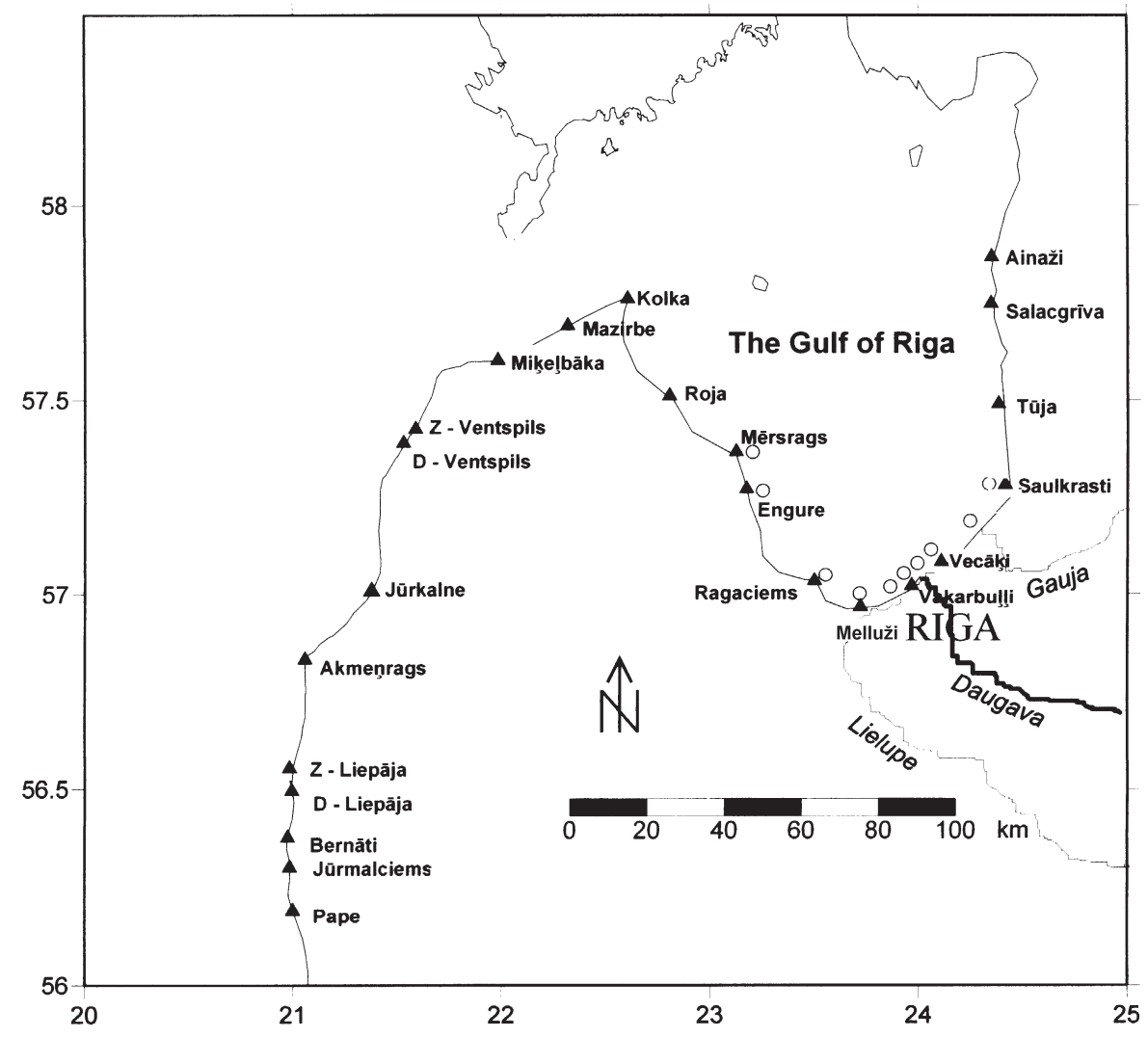

Fig. 2. Sampling stations at the open Baltic coast and in the Gulf of Riga

A littoral stations (1 m depth), $\bigcirc$ sublittoral stations (10 m depth). 
MEAN, MINIMUM AND MAXIMUM VALUES OF THE PARAMETERS MEASURED IN THE GULF OF RĪGA LITTORAL ZONE AT SAMPLING STATIONS AND CALCULATED VALUES OF TRIX

\begin{tabular}{|c|c|c|c|c|c|c|c|c|c|c|c|c|c|c|c|}
\hline \multirow[t]{2}{*}{ PARAMETRES } & \multicolumn{3}{|c|}{ 1999, SUMMER } & \multicolumn{3}{|c|}{ 2001, SUMMER } & \multicolumn{3}{|c|}{ 2003, SUMMER } & \multicolumn{3}{|c|}{ 2005, SUMMER } & \multicolumn{3}{|c|}{ 2005, WINTER } \\
\hline & mean & $\min$ & $\max$ & mean & $\min$ & $\max$ & mean & $\min$ & $\max$ & mean & $\min$ & $\max$ & mean & $\min$ & $\max$ \\
\hline Temperature, ${ }^{\circ} \mathrm{C}$ & 21.0 & 18.0 & 23.5 & 19.9 & 18.2 & 21.4 & 22.9 & 20.8 & 24.5 & 17.7 & 12.0 & 22.6 & 2.2 & 1.6 & 3.7 \\
\hline Salinity, psu & 4.39 & 3.93 & 4.69 & 4.71 & 3.82 & 5.38 & 5.12 & 4.55 & 5.61 & 4.78 & 3.77 & 5.51 & 4.76 & 2.18 & 5.29 \\
\hline $\mathrm{Chl} a, \mathrm{mg} / \mathrm{m}^{3}$ & 7.0 & 3.3 & 13.8 & 10.2 & 5.3 & 18.5 & 3.1 & 0.6 & 8.3 & 9.6 & 5.4 & 21.2 & 1.9 & 1.5 & 2.4 \\
\hline $\mathrm{N}-\mathrm{NH}_{4}, \mu \mathrm{M}$ & 0.4 & 0.0 & 1.6 & 0.1 & 0.0 & 0.2 & 0.4 & 0.2 & 0.6 & 0.3 & 0.0 & 0.6 & 4.3 & 2.4 & 8.3 \\
\hline $\mathrm{N}-\mathrm{NO}_{2}, \mu \mathrm{M}$ & 0.02 & 0.00 & 0.16 & 0.07 & 0.00 & 0.53 & 0.01 & 0.00 & 0.03 & 0.08 & 0.02 & 0.21 & 0.32 & 0.20 & 0.54 \\
\hline $\mathrm{N}-\mathrm{NO}_{3}, \mu \mathrm{M}$ & 0.7 & 0.1 & 2.9 & 1.3 & 0.1 & 8.5 & 0.1 & 0.0 & 0.4 & 0.5 & 0.0 & 3.0 & 16.9 & 9.9 & 57.6 \\
\hline $\mathrm{DIN}, \mu \mathrm{M}$ & 1.1 & 0.2 & 4.6 & 1.5 & 0.1 & 9.0 & 0.5 & 0.2 & 0.8 & 0.8 & 0.2 & 3.4 & 21.6 & 13.7 & 62.0 \\
\hline 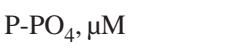 & 0.25 & 0.00 & 0.45 & 0.10 & 0.00 & 0.36 & 0.08 & 0.01 & 0.24 & 0.18 & 0.03 & 0.29 & 0.61 & 0.38 & 0.83 \\
\hline P-tot, $\mu \mathrm{M}$ & 1.58 & 1.02 & 2.55 & 1.74 & 1.30 & 3.02 & 1.89 & 0.70 & 3.02 & 1.37 & 0.70 & 2.55 & 0.93 & 0.70 & 1.16 \\
\hline D.O., ml/1 & 6.04 & 5.26 & 6.43 & 6.42 & 6.10 & 7.01 & 6.68 & 5.35 & 9.60 & 7.41 & 6.59 & 9.56 & 8.86 & 8.30 & 9.53 \\
\hline $\mathrm{O}_{2}$, sat. $\%$ & 99.4 & 87.3 & 110.1 & 103.8 & 98.2 & 111.1 & 114.6 & 92.8 & 163.0 & 114.7 & 95.0 & 162.6 & 98.1 & 93.3 & 100.2 \\
\hline TRIX & 4.37 & 3.48 & 5.23 & 4.62 & 3.95 & 5.83 & 4.56 & 3.76 & 5.02 & 4.97 & 4.39 & 6.13 & 4.91 & 4.07 & 5.37 \\
\hline
\end{tabular}

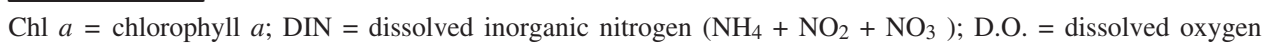

year. Mean values of phosphorus (P-tot, $\mu \mathrm{M}$ ) from 1999 to 2003 increased from 1.58 to $1.89 \mu \mathrm{M}$ and decreased in 2005 to $1.37 \mu \mathrm{M}$ (Table 1). In general, these parameters do not provide a clear picture of coastal water condition and quality. TRIX and mean values from 1999 to 2005 clearly showed an absence of improvement of water quality and warned of worsening of water quality (Table 1, Fig. 4). Also during winter, low chlorophyll $a$ and relatively higher values of nitrogen and phosporus make the Trophic State Index comparable with summer values (Table 1).

Figure 3 shows the distribution of TRIX values from the shallow coastal zone $(1.0 \mathrm{~m})$ to sublittoral zone $(10 \mathrm{~m})$. Especially high values of TRIX (5-6) were observed close to the Riga city wastewater treatment plant outlet area and in the river Lielupe and Daugava estuaries, clearly illustrating the anthropogenic impact.

Physical, chemical parameters and TRIX at the open Baltic coast. Monitoring data for the open Baltic coast in the Latvian part are very scarce, and the values presented in Table 2 are the first regular observation data for this region. Therefore, during 2006, three surveys were conducted to characterise the water quality also seasonally.
As predicted, the values of the measured parameters differ from these in the Gulf of Riga. Comparison of two summer periods showed a lower temperature, chlorophyll $a$ values and higher salinity (range from 5.92 to $7.34 \mathrm{psu}$ ). This is reflected also by the TRIX values, especially during late spring (June) 2006, when the mean value for 12 stations was only 3.68. During summer the TRIX values in both years were above 4 (4.02 and 4.36, respectively). The observed maximum values were high 4.89 and 5.50, illustrating a relatively high trophic state also for open coastal littoral zone water quality at stations mainly located close to the Lithuanian border in 2005 (Pape, Jūrmalciems) and during summer survey in 2006, close to Irbe Strait (Mazirbe, Mik̦elbāka).

\section{DISCUSSION}

User-friendly ecological indicators and especially these incorporating a holistic approach have been recommended recently for marine quality assessments. The Baltic Sea, with large surrounding drainage basins and abundant river inflows is recently claimed as a particularly vulnerable system needing adaptive management (Anonymous, 2001; Elmgren, 2001; Loureilo et al., 2006; Salas et al., 2006; Coelho

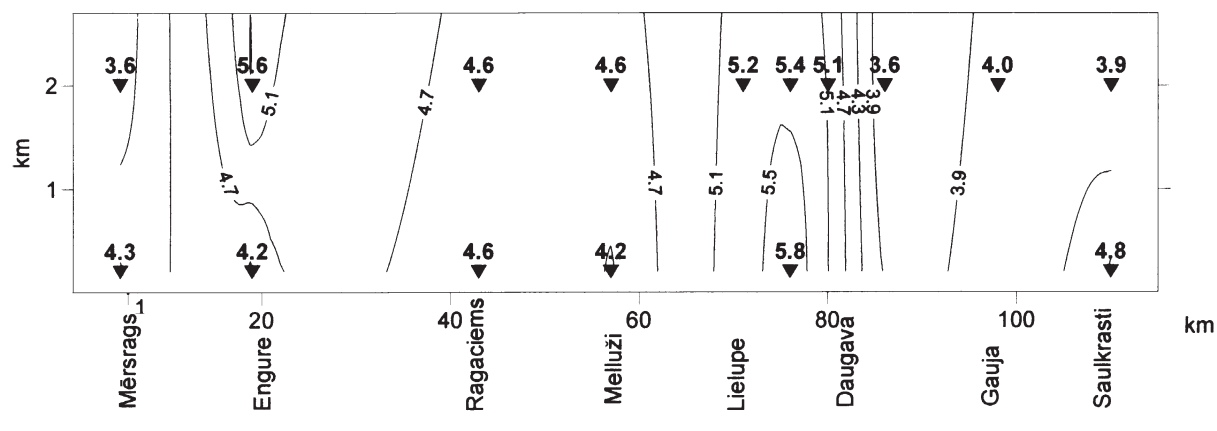

Fig. 3. TRIX values distribution in the sublittoral zone of the Gulf of Rìga. 
MEAN, MINIMUM AND MAXIMUM VALUES OF THE PARAMETERS MEASURED AT THE BALTIC SEA OPEN COAST LITTORAL ZONE AT THE SAMPLING STATIONS AND CALCULATED VALUES OF TRIX

\begin{tabular}{|c|c|c|c|c|c|c|c|c|c|c|c|c|}
\hline \multirow[t]{2}{*}{ PARAMETERS } & \multicolumn{3}{|c|}{ 2005, SUMMER } & \multicolumn{3}{|c|}{ 2006, SPRING } & \multicolumn{3}{|c|}{ 2006, SUMMER } & \multicolumn{3}{|c|}{ 2006, FALL } \\
\hline & mean & $\min$ & $\max$ & mean & $\min$ & $\max$ & mean & $\min$ & $\max$ & mean & $\min$ & $\max$ \\
\hline Temperature, ${ }^{\circ} \mathrm{C}$ & 19.8 & 18.6 & 20.8 & 12.6 & 11.2 & 16.4 & 17.8 & 13.8 & 22.0 & 16.8 & 15.6 & 17.8 \\
\hline Salinity, psu & 6.54 & 6.20 & 6.87 & 6.44 & 5.92 & 6.92 & 6.89 & 5.37 & 7.34 & 6.45 & 5.63 & 6.99 \\
\hline Chl $a, \mathrm{mg} / \mathrm{m}^{3}$ & 4.0 & 1.8 & 5.8 & 3.2 & 0.6 & 11.5 & 4.4 & 1.9 & 12.3 & 5.0 & 3.6 & 7.4 \\
\hline $\mathrm{N}-\mathrm{NH}_{4}, \mu \mathrm{M}$ & 0.4 & 0.2 & 0.6 & 0.5 & 0.3 & 0.9 & 0.3 & 0.0 & 0.8 & 0.5 & 0.1 & 2.0 \\
\hline $\mathrm{N}-\mathrm{NO}_{2}, \mu \mathrm{M}$ & 0.04 & 0.02 & 0.07 & 0.05 & 0.01 & 0.11 & 0.01 & 0.00 & 0.03 & 0.06 & 0.03 & 0.14 \\
\hline $\mathrm{N}-\mathrm{NO}_{3}, \mu \mathrm{M}$ & 0.1 & 0.0 & 0.3 & 0.2 & 0.0 & 0.5 & 0.2 & 0.0 & 0.6 & 0.5 & 0.2 & 1.3 \\
\hline $\mathrm{DIN}, \mu \mathrm{M}$ & 0.5 & 0.3 & 0.8 & 0.7 & 0.4 & 1.5 & 0.5 & 0.1 & 1.3 & 1.1 & 0.5 & 3.3 \\
\hline $\mathrm{P}-\mathrm{PO}_{4}, \mu \mathrm{M}$ & 0.09 & 0.03 & 0.25 & 0.17 & 0.08 & 0.28 & 0.18 & 0.03 & 0.34 & 0.23 & 0.09 & 0.55 \\
\hline P-tot, $\mu \mathrm{M}$ & 2.14 & 1.28 & 2.78 & 0.70 & 0.51 & 1.02 & 1.06 & 0.44 & 2.62 & 0.93 & 0.46 & 1.39 \\
\hline D.O., ml/l & 6.12 & 5.68 & 6.39 & 7.15 & 6.11 & 7.49 & 6.61 & 5.44 & 7.32 & 6.93 & 6.53 & 8.29 \\
\hline $\mathrm{O}_{2}$, sat. $\%$ & 99.9 & 92.6 & 102.8 & 100.2 & 82.7 & 104.2 & 104.0 & 78.4 & 114.9 & 106.5 & 101.3 & 129.1 \\
\hline TRIX & 4.02 & 3.29 & 4.89 & 3.68 & 2.92 & 4.94 & 4.36 & 3.74 & 5.50 & 4.48 & 3.82 & 5.00 \\
\hline
\end{tabular}

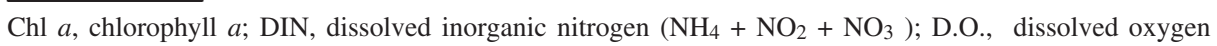

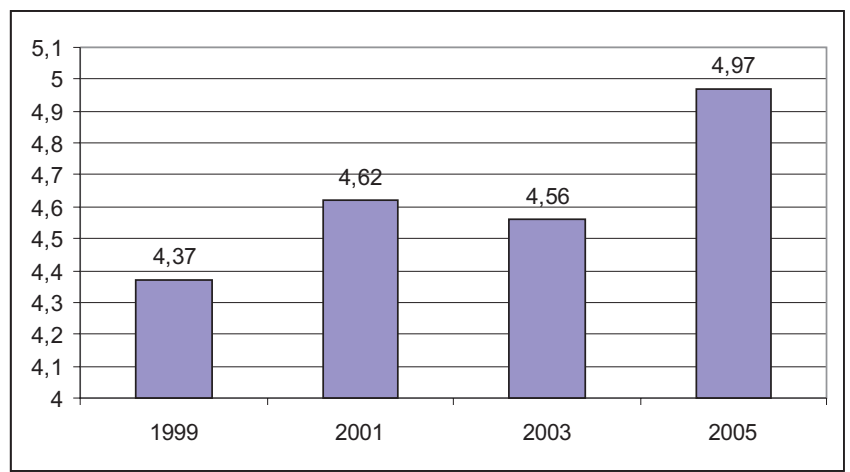

Fig. 4. Trophic State Index mean values in littoral stations in the Gulf of Rīga.

et al., 2007). In this complex system indices for quality assessment are needed.

The Gulf of Rìga as a part of the Baltic Sea where monitoring has continues for a long time, could be used as test system for environment indices, especially based on the holistic approach, such as TRIX (Vollenweider et al., 1998). The spatial variation of physical, chemical and biological water parameters among stations in the Gulf of Riga and the open shallow coast of the Baltic Sea is high and the large data set (Tables 1 and 2) does not allow to understand water quality changes and to make comparisons between the stations and subregions, especially between the years for the same region.

However, TRIX values are very sensitive and any slight change of oxygen, chlorophyl $a$, dissolved inorganic nitrogen and total phosphorus concentrations results in changed index values. Only TRIX values allow to implement scoring between stations which is important in evaluation of processes of different subregions. According to recent publications (Coelho et al., 2007, Pettine et al., 2007) it was suggested that: TRIX in the range 2-4 characterised low productivity waters, and a range of 5-8 described highly productive waters with a high trophic level and moderate/poor water quality.

The European Environmental Agency (Anonymous, 2001) has already tested this index and suggested that the range of TRIX should be defined for different regions in Europe in order to increase the index sensibility and representativeness.

Recently this composite index adopted by Italian legislation for the classification of the trophic status in Italian coastal waters was applied for classification of Slovenian coastal waters, Northern European seas, and the Black Sea (Anonymous, 2001; Pettine et al., 2007).

Our results illustrate that the TRIX obtained for several years could serve as a possible trend parameter for water quality changes in the Gulf of Riga. In the case for the open Baltic coast more data is needed, but the first results at least allow to compare the trophic state of littoral zones for two subregions-open coast and gulf waters.

The Trophic State Index could also be implemented for historical data sets from monitoring surveys because all of the needed parameters are a part of the monitoring programme for every country around the Baltic. This means also that the index obtained from already existing monitoring programmes in fact is very cost-effective in use.

The first attempt to assess the TRIX index and its links with the Baltic coastal ecosystem elements like species diversity and density was made in 2003 (Boikova et al., 2003) by characterising the littoral habitats in the Gulf of Riga. These first results showed that decreasing TRIX values (from 4.8 to 3.8 ) were followed by increasing macrozoobenthos and macrophyte species diversity. This shows that TRIX also could be used as an indirect parameter of system diversity, but more correlation analyses are needed both for plankton, benthos communities and TRIX values. 


\section{ACKNOWLEDGMENTS}

This study was supported by the Latvian Council of Science, Project 03.0999 „Functional Biodiversity of the Gulf of Rìga” and Project 000125.3.1. „Biological resources and the risks to their quality at the open Baltic coast".

\section{REFERENCES}

Anonymous (2001). Eutrophication in Europe's Coastal Waters. Topic Report No. 7. Copenhagen: European Environmental Agency. 86 pp.

Anonymous (2003). A Reference Guide on the Use of Indicators for Integrated Coastal Management. ICAM Do IOC Manuals and Guides, UNESCO, Vol. 45, 110 pp.

Anonymous (2006). Focus on sustainable development. Nordic Indicators 2006. Copenhagen: Nord 2006:003. 112 pp.

Boikova, E., Botva, U., Līcīte, V., Jermakovs, V., Kulikova, I., Seisuma, Z., Petrovics, N. (2003). The littoral biotopes of the Gulf of Rìga and their role in sustainable coastal zone development. In Proceedings of the ECO-BALT International Conference, Rīga, 15-16 May 2003 (pp. 73-75). Rīga.

Coelho, S., Gamito, S., Pčrez-Ruzafa, A. (2007). Trophic state of FOZ de Almargem coastal lagoon (Algarve, South Portugal) based on the water quality and the phytoplankton community. J. Estuarine Coastal Shelf Sci., 71(1-2), 218-231.

Received 1 April 2008
Elmgren, R. (2001). Understanding human impact on the Baltic Sea ecosystem: Changing views in recent decades. AMBIO, J. Hum. Environ., 30(4-5), 222-231.

Grasshoff, K. (1976). Methods of sea water analysis. Weinheim; New York: Verlag Chemie. 317 pp.

Grasshoff, K., Ehrhardt, M., Kremling, K. (1983). Methods of Sea Water Analysis. 2nd ed. Weinheim; Basel: Verlag Chemie. 419 pp.

Loureiro, S., Newton, A., Icely, J. (2006). Boundary conditions for the European Water Framework Directive in the Ria Formosa lagoon, Portugal (physico-chemical and phytoplankton quality elements. J. Estuarine Coastal Shelf Sci., 67, 382-398.

Pettine M., Casentini, B., Fazi, S., Giovanardi, F., Pagnotta, R. (2007). A revisitation of TRIX for trophic status assessment in the light of the European Water Framework Directive: Application to Italian coastal waters. Mar. Poll. Bull., 54(9), 1413-1428.

Salas, F., Marcos, C., Neto, J.M., Patricio, J., Pčrez-Ruzafa, A., Marques, J.C. (2006). User-friendly guide for using benthic ecological indicators in coastal and marine quality assessment. J. Ocean Coastal Manag., 49(5-6), 308-331.

Strickland, J.D.H., Parsons, T.R. (1972). A Practical Handbook of Seawater Analyses. 2nd ed. Otawa: Fisheries Research Board of Canada. 167 pp.

Vollenweider, R.A., Giovanardi, F., Montanari,G., Rinaldi, A. (1998). Characterisation of the trophic conditions of marine coastal waters with special reference to the NW Adriatic Sea: Proposal for a trophic scale, turbidity and generalised water quality index. Environmetrics, 9, 329-357.

\section{TROFISKĀ INDEKSA LIETOJUMS BALTIJAS JŪRAS UN RĪGAS Lİ̌̌A PIEKRASTES ŪDEN̦U INTEGRĒTAM KVALITĀTES NOVĒRTĒJUMAM}

Jūras vides un jo sevišḳi piekrastes ūdeņu kvalitātes izvērtěšana ir viena no jaunajām Eiropas ūdeņu struktūrdirektīvas prasībām. Vides kvalitātes izvērtējumam jūras piekrastes ūdenos arvien vairāk sāk lietot indeksus, kas zinātnisko informāciju dara saprotamu vides apsaimniekošanas speciālistiem un sabiedrībai. Samērā nesen sevišķa uzmanība tikusi pievērsta integrētiem rādītājiem. Pētījums veikts ar mērķi raksturot Baltijas jūras piekrastes un Rīgas līča litorāla/sublitorāla eitrofikācijas slodzes izvērtējumu ar trofiskā indeksa (TRIX) palīdzību. Rezultāti liecina, ka trofisko indeksu raksturo augsta jutīguma pakāpe un tas labi raksturo Baltijas jūras piekrastes ūdeṇu trofiskuma pakāpes izmainas. 